\title{
Isolation and Contractile Properties of Single Smooth Muscle Cells from Guinea Pig Taenia Caeci
}

\author{
Kazuo ObaRA \\ Department of Physiology, Sapporo Medical College, \\ Sapporo, Hokkaido, 060 Japan
}

\begin{abstract}
A method for the isolation of single smooth muscle cells from guinea pig taenia caeci is described. The single cells were prepared by digestion with $0.3 \%$ collagenase and $0.6 \%$ trypsin inhibitor in $\mathrm{Ca}^{2+}$ free solution. This procedure produced a high yield of intact cells. Most cells obtained by this procedure were relaxed and showed large contractile responses to excitatory stimulus. Maximal responses of the single cells to acetylcholine ( $\mathrm{ACh}$ ), histamine, and high $\mathrm{K}^{+}$were attained within $20 \mathrm{sec}$, and the per cent decrease in cell length was 30 $40 \%$. Times for maximal responses of the single cells were shorter than those of the muscle strips. Single cells exhibited a dose-dependent graded response to calcium under depolarized conditions, ACh, histamine, and high $\mathrm{K}^{+}$, and a voltage- and duration-dependent response to electrical stimulation. The $\mathrm{ED}_{50} \mathrm{~s}$ of $\mathrm{ACh}$ in the single cells and in the muscle strips were about $2 \times 10^{-8}$ and $1.5 \times 10^{-7} \mathrm{M}$, respectively. The muscle strips had a lower sensitivity than the single cells to ACh. The generally smooth surface of the relaxed cell contrasted with the numerous evaginations present on the fully contracted cell. I believe that single smooth muscle cells isolated from guinea pig using my technique are, at present, better for physiological and pharmacological studies than are cells isolated using other techniques.
\end{abstract}

Key Words: single cells, smooth muscle cells, taenia caeci, guinea pig, graded response.

The basic aspects of excitation-contraction coupling (E-C coupling) in smooth muscle are not known with the same degree of certainty that exists for striated muscle. If it were possible to correlate measurements of transmembrane potential, intracellular $\mathrm{Ca}^{2+}$ and contraction in the same single cell, the mechanism of E-C coupling in smooth muscle might be better understood. Furthermore, cell dispersion would eliminate intercellular coupling and minimize the diffusion barriers which are formed by the existence of the matrix of the extracellular

Received for publication August 24, 1983

小原一男 
space and thus facilitate exact analysis of inward and outward ionic fluxes through cell membranes. Some progress in this direction has recently been made by the development of methods for the enzymatic isolation of smooth muscle cells, and by observation of structural change and measurement of shortening force produced by various stimulants and electrical activity in these single cells (BAGBY and FISHER, 1973; Fay and Delise, 1973; Fay and Singer, 1977; Momose and Gomi, 1978, 1980; WALSH and Singer, 1981; BiTAR et al., 1979).

In this paper, I report the development of an isolation method, some properties of the contractile response of isolated single cells to stimulants, and structural change occurring during contraction.

\section{MATERIALS AND METHODS}

Cell preparation. A suspension of isolated smooth muscle cells from guinea pig taenia caeci was prepared by a modification of the method of MoMOSE and Gomi (1980). Strips of taenia caeci, 4-5 cm in length, were excised from freshly killed guinea pigs weighing $300-600 \mathrm{~g}$. They were placed, at $35^{\circ} \mathrm{C}$ for $30 \mathrm{~min}$, in a modified Tyrode solution bubbled with air and then for $15 \mathrm{~min}$ in $\mathrm{Ca}^{2+}$-free modified Tyrode solution. Each strip was minced and then suspended with gentle stirring 2-3 times/sec for $30 \mathrm{~min}$ in $2 \mathrm{ml}$ of $\mathrm{Ca}^{2+}$-free modified Tyrode solution containing $0.3 \%$ collagenase, $0.6 \%$ trypsin inhibitor, and $1.0 \%$ bovine serum albumin. The suspension was diluted with $8 \mathrm{ml}$ of $\mathrm{Ca}^{2+}$-free modified Tyrode solution containing $1.0 \%$ albumin and was centrifuged at $1,000 \mathrm{rpm}$ for $3 \mathrm{~min}$. The precipitate was suspended with gentle stirring for $15 \mathrm{~min}$ in $3 \mathrm{ml}$ of $\mathrm{Ca}^{2+}$. free modified Tyrode solution and then dispersed by pipetting the suspension with a wide-bored pipette (diameter; $2 \mathrm{~mm}$ ). The suspension was allowed to stand for 2-3 min. The precipitate was then divided into two portions. One portion was resuspended in $3 \mathrm{ml}$ of $\mathrm{Ca}^{2+}$-free modified Tyrode solution and another portion in $3 \mathrm{ml}$ of $140 \mathrm{mM} \mathrm{K}^{+}$solution. The latter suspension was observed for calcium contraction. The cell suspensions were filtered through nylon mesh and the filtrates were used for the experiments. In the former case, the suspension was finally prepared by addition of $\mathrm{CaCl}_{2}$ to a final concentration of $1.8 \mathrm{~mm}$. The cells were counted using a hemocytometer, a piece of taenia caeci $4-5 \mathrm{~cm}$ in length yielding about $10^{4}-10^{5}$ muscle cells. The cells excluded trypan blue to the extent of 90 out of every 100 cells.

The composition of the modified Tyrode solution was $137 \mathrm{mM} \mathrm{NaCl}, 2.7 \mathrm{mM}$ $\mathrm{KCl}, 0.18 \mathrm{~mm} \mathrm{CaCl}_{2}, 1 \mathrm{~mm} \mathrm{MgCl}_{2}, 5.6 \mathrm{~mm}$ glucose, and $4.2 \mathrm{~mm}$ HEPES $(N-2-$ hydroxyethylpiperazine- $N^{\prime}$-2-ethanesulfonic acid), $\mathrm{pH}$ 7.4. High $\mathrm{K}^{+}$solution was prepared by replacing the $\mathrm{NaCl}$ in $\mathrm{Ca}^{2+}$-free modified Tyrode solution with isosmotic $\mathrm{KCl}$.

Measurement of contractile response. The technique for stimulation was similar to that described by BITAR et al. (1979). Aliquots consisting of $5 \times 10^{3}$ 
cells in $0.5 \mathrm{ml}$ were added to $0.1 \mathrm{ml}$ of solution containing the agent or $\mathrm{CaCl}_{2}$ to be tested, thereby ensuring rapid mixing. For the electrical stimulation, cells were pipetted into a chamber having two platinum wires $8 \mathrm{~mm}$ apart which were connected to an electrical stimulator (MSE-3R, Nihon Kohden) and isolation unit (MSE-JM, Nihon Kohden), and then a DC field stimulus was passed through the droplet containing the cells. At the end of the reaction time, $0.1 \mathrm{ml}$ of acrolein was added to make a final concentration of $1 \%$.

The contractile response was defined as the decrease in the average length of a population of muscle cells exposed to a test agent or to applied electrical stimulation. An aliquot of cell suspension, fixed with acrolein, was placed on a glass slide under a coverslip and was scanned on a phase-contrast microscope (FHA, Olympus) and many photomicrographs of successive fields were taken to include $80-120$ cells for each stimulatory modality. The photomicrographs were projected onto a paper screen and the mean cell lengths were measured from enlarged photomicrographs.

Isolated single cells were perfused continuously with modified Tyrode solution on dimethyldichlorosilane-coated slide glass and $\mathrm{CaCl}_{2}$; otherwise another stimulatory agent was applied with perfusate. Contraction of the cells was observed continuously using a phase-contrast microscope, and the length of the cell was determined by measuring the cell size on a microphotograph (MOMOSE and GomI, 1977).

The contraction induced by acetylcholine $(\mathrm{ACh})$ and calcium in muscle strips of guinea pig taenia caeci was measured isometrically. A muscle strip $(0.5 \times$ $3.0 \mathrm{~mm}$ ) was incubated in an organ bath containing $\mathrm{Ca}^{2+}$-free modified Tyrode solution. The isometric tension induced by addition of $\mathrm{ACh}$ or calcium was then recorded on a pen recorder (WI-180, Nihon Kohden) using a force-displacement transducer (SB-1T, Nihon Kohden).

Electron microscopy. Structural changes associated with the contraction of isolated cells were studied with a scanning electron microscope. A cell suspension was retained on a glass slide coated with $4 \%$ gelatin in $140 \mathrm{mM} \mathrm{K}^{+}$solution. Contraction of cells retained on the gelatin was induced by addition of calcium and the cell was fixed by the injection of glutaraldehyde in $\mathrm{Ca}^{2+}$-free modified Tyrode solution. The glass slide was immersed in $2.5 \%$ glutaraldehyde at $4^{\circ} \mathrm{C}$ for $2 \mathrm{hr}$ and then washed in cacodylate buffer solution at $4^{\circ} \mathrm{C}$ for $2 \mathrm{hr}$ and dehydrated in acetone. Then the glass slide was transferred into amyl acetate. The slide with the attached cells was dried using the critical-point method and coated with a layer of $\mathrm{Au}$. The slide was observed using a scanning electron microscope (MSM 4C-101, Hitachi and Akashi Co.).

Chemicals. Collagenase (Type I) and bovine serum albumin (Fraction V) were obtained from Sigma Chemical Co., U.S.A. Soybean trypsin inhibitor came from Miles Laboratories. Histamine hydrochloride and dimethyldichlorosilane were purchased from Wako Pure Chemical Industries, Ltd. and acetylcholine 
(Ovisot) was obtained from Daiichi Seiyaku Co., Ltd. $N$-2-hydroxyethylpiperazine- $N^{\prime}$-2-ethanesulfonic acid (HEPES) was obtained from Dojin Chemicals Co. Other chemicals were of guaranteed grade.

\section{RESULTS}

Morphometric profile of taenia caeci smooth muscle cells

Observations were made using a phase-contrast microscope. As shown in Fig. 1, isolated smooth muscle cells varied widely in length, and some were fully relaxed while others were in various states of contraction. The distribution of cell length in the control state is shown in Fig. 2. The cell length range (40-260 $\mu \mathrm{m})$ and mean cell length ( $130.3 \pm 7.3 \mu \mathrm{m}, n=14$ experiments) were similar to those found in the stomach of guinea pig (BITAR and MAKHLOUF, 1982). Ten per cent of the cells were longer than $180 \mu \mathrm{m}$ and $10 \%$ were shorter than $70 \mu \mathrm{m}$. No spontaneous contraction was observed in any cells. Cells which were able to respond to stimulatory agents were rounded in cross section, spindle-shaped, and not transparent.

\section{Contraction of isolated smooth muscle cells}

All cell suspensions were studied within the first $1 \mathrm{hr}$. After this period, the numerous cells capable of contractile responses were absent. The contractile responses to acetylcholine ( $\mathrm{ACh}$ ), histamine, high $\mathrm{K}^{+}$, and to electrical stimulation were prompt, rising to a peak within $20 \mathrm{sec}$ (Fig. 3). The slope of the rise was steep. After the peak, contraction declined to a plateau. The structural changes associated with contraction due to ACh may be divided into four patterns. As may be seen from Fig. 4, which depicts a typical contractile response to ACh $\left(10^{-4} \mathrm{M}\right.$ ), the cells contracted in a synchronous, uniform manner (see $\rightarrow$ on the left side of the photograph in Fig. 4B). During contraction, in the fully contracted cell numerous blebs (darts) appeared along the cell surface (see the center of the photograph in Fig. 4B). Similar changes in the cell surface were also associated with contractions induced by histamine, by calcium under depolarized conditions, and by electrical stimulation. Even in the presence of $\mathrm{ACh}$, cells were partially relaxed, and this partial relaxation was accompanied by the disappearance of the blebs (see $\rightarrow$ in the center of the photograph in Fig. 4C). The cell situated in the lower, left-hand side of the pictures in Fig. $4(\Rightarrow)$ did not respond to ACh.

Figure 5B shows a typical scanning electron micrograph of a cell fixed at the state of full contraction induced by calcium under depolarized conditions (140 $\mathrm{mM} \mathrm{K}^{+}$) in which evaginations were remarkably similar to those shown in Fig. 4B. The cell surface was covered by vesicles and bulbous projections. The numerous evaginations present on the fully contracted cell contrast with the generally smooth surface of the relaxed cell. The smooth appearance was charac- 


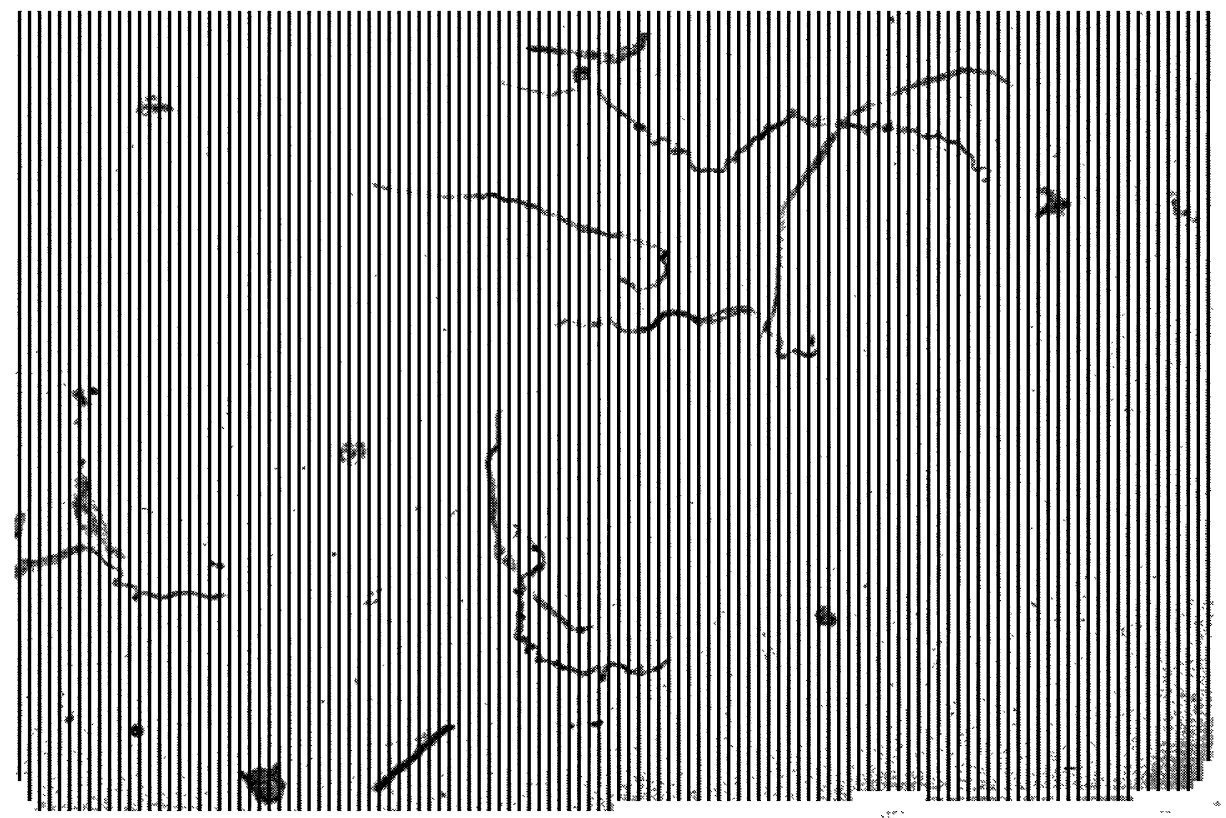

Fig. 1. Isolated single smooth muscle cells from guinea pig taenia caeci on incubation with collagenase and trypsin inhibitor in $\mathrm{Ca}^{2+}$-free modified Tyrode solution. Scale represents $100 \mu \mathrm{m}$.

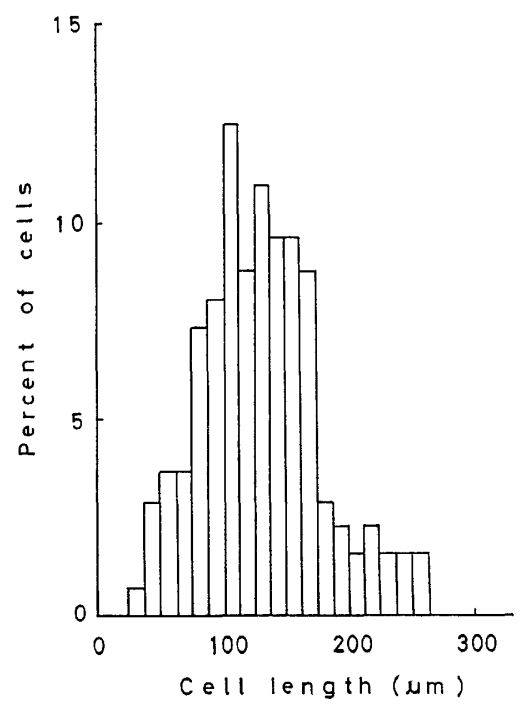

Fig. 2. Distribution of muscle cell lengths in the control state. Cell lengths were measured from enlarged photomicrographs of numerous random fields in the control state $(n=236$ cells). 


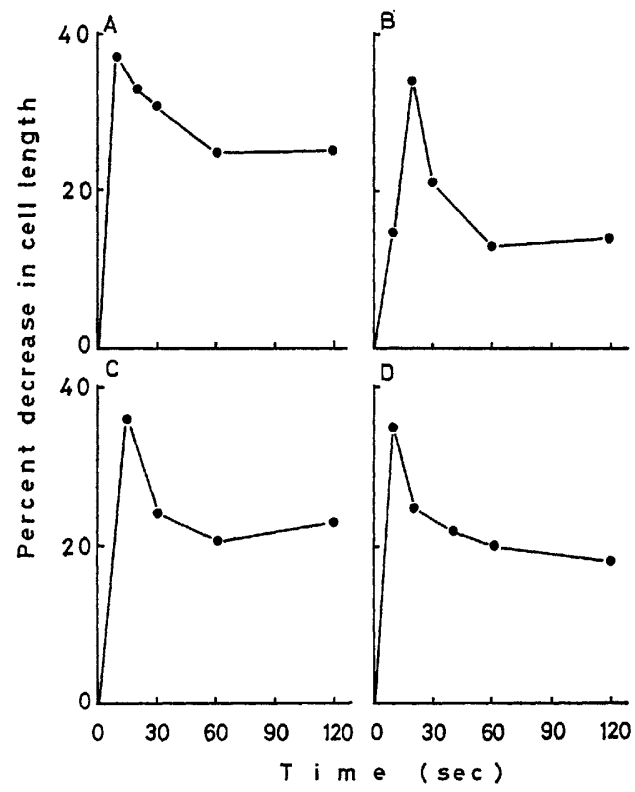

Fig. 3. Typical time course for response of isolated smooth muscle cells from guinea pig taenia caeci to excitatory stimulus in modified Tyrode solution $\left(1.8 \mathrm{~mm} \mathrm{Ca}{ }^{2+}\right)$. Data were expressed as per cent decrease in cell length. A, ACh $\left(10^{-4} \mathrm{M}\right) ; \mathrm{B}$, histamine $\left(10^{-4}\right.$ $\mathrm{M})$; C, high $\mathrm{K}^{+}(85 \mathrm{~mm})$; D, electrical stimulation (140 V, $\left.20 \mathrm{msec}\right)$.

teristic of cells fixed in a relaxed state, irrespective of whether they had been made to contract previously (Fig. 5A).

\section{Effect of acetylcholine}

The contractile response of isolated single cells to ACh was dose-dependent (Fig. 6). The maximal response to ACh $\left(10^{-4} \mathrm{M}\right)$ expressed as the per cent decrease in mean cell length from the control was $38 \%$ (Fig. 3A). The maximal response to $\mathrm{ACh}$ did not differ significantly from the maximal response to histamine $\left(10^{-4} \mathrm{M}\right)$, high $\mathrm{K}^{+}(>100 \mathrm{~mm})$, or $4 \mathrm{~mm}$ calcium. The threshold concentration of $\mathrm{ACh}$ to induce contraction was approximately $10^{-8} \mathrm{M}$. The $\mathrm{ED}_{50}$, estimated graphically, was about $2 \times 10^{-8} \mathrm{M}$. Atropine $\left(10^{-6} \mathrm{M}\right)$ specifically inhibited the response to $\mathrm{ACh}$ and shifted the $\mathrm{ACh}$ dose-response curve to the right. On the other hand, muscle strips of taenia caeci responded maximally to $10^{-5} \mathrm{M} \mathrm{ACh}$, and $\mathrm{ED}_{50}$ was about $1.5 \times 10^{-7} \mathrm{M}$.

Fig. 4. Contraction of isolated smooth muscle cells from guinea pig taenia caeci caused by $10^{-4} \mathrm{M}$ ACh in modified Tyrode solution $\left(1.8 \mathrm{mM} \mathrm{Ca}^{2+}\right)$. A, before exposure to $\mathrm{ACh}$; $\mathrm{B}, 10 \mathrm{sec}$ after exposure to $\mathrm{ACh} ; \mathrm{C}, 2 \mathrm{~min}$ after exposure to $\mathrm{ACh}$. The single cells were perfused on silicone-coated glass slides and ACh was applied. The irregularity of the surface (darts) in the fully contracted cell (B) compared with the relaxed cell (A). Scale represents $100 \mu \mathrm{m}$. 



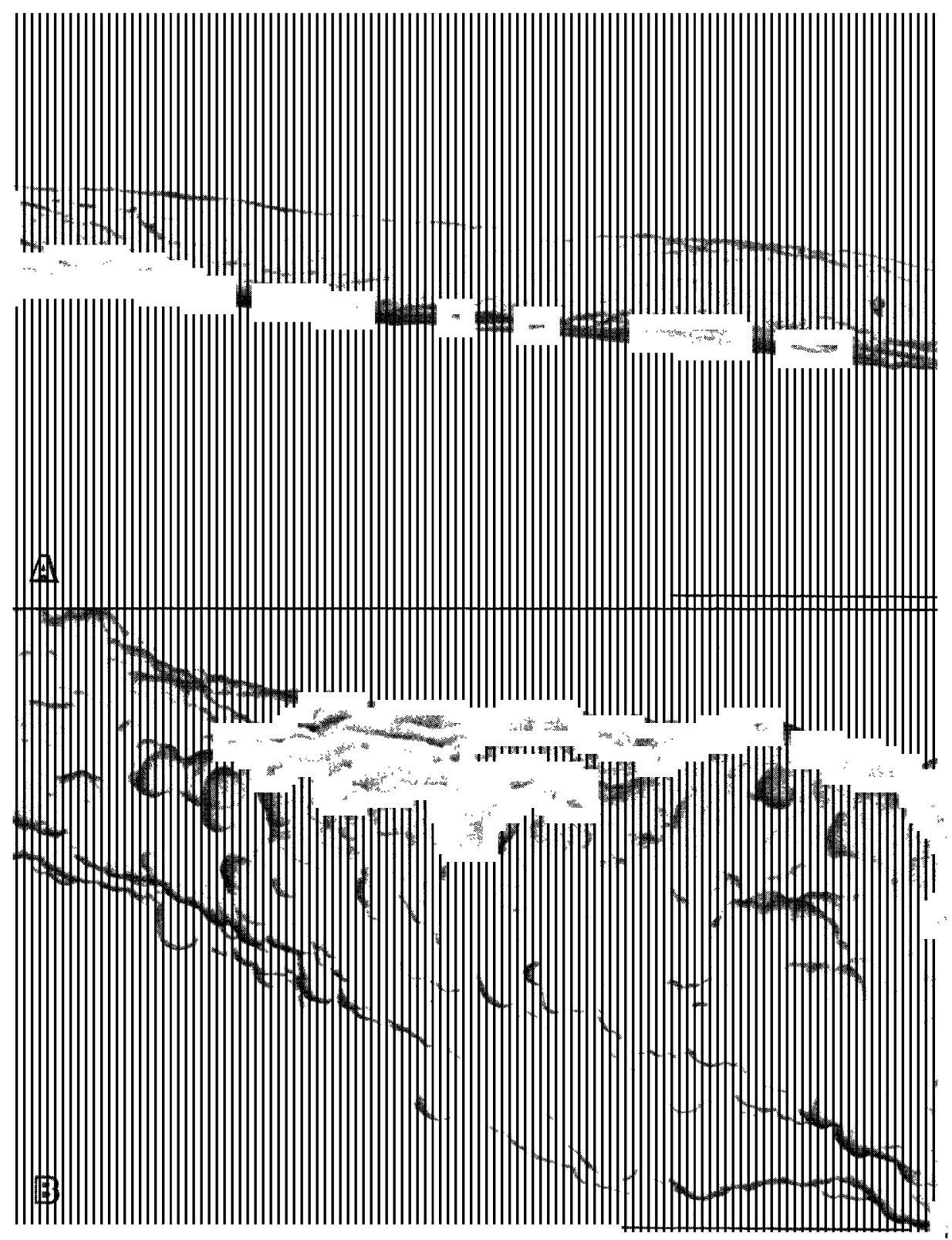

Fig. 5. Scanning electron micrograph of isolated smooth muscle cell from guinea pig taenia caeci. A, single cell fixed in relaxed state (in $140 \mathrm{~mm} \mathrm{~K}^{+}$solution); B, single cell fixed after shortening induced by the application of $10 \mathrm{~mm}$ calcium under depolarized conditions $\left(140 \mathrm{~mm} \mathrm{~K} \mathrm{~K}^{+}\right)$. Scale represents $5 \mu \mathrm{m}$. 


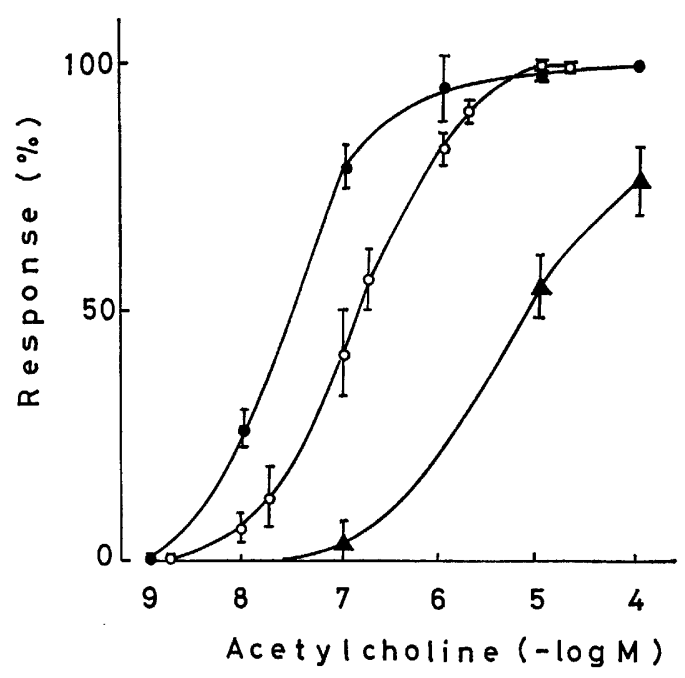

Fig. 6. Dose-response curve to $\mathrm{ACh}$ for several cell suspensions and several muscle strips from guinea pig taenia caeci. Cell suspensions were exposed to various concentrations of $\mathrm{ACh}$ in modified Tyrode solution $\left(1.8 \mathrm{mM} \mathrm{Ca}^{2+}\right)$ for $10 \mathrm{sec}$ in the presence $(\boldsymbol{\Lambda})$ and absence (๑) of $10^{-8} \mathrm{M}$ atropine. Contraction of muscle strips $(O)$ was determined isometrically. Data were normalized against maximal response obtained. Each point is mean \pm S.E. $(n=4-6)$.

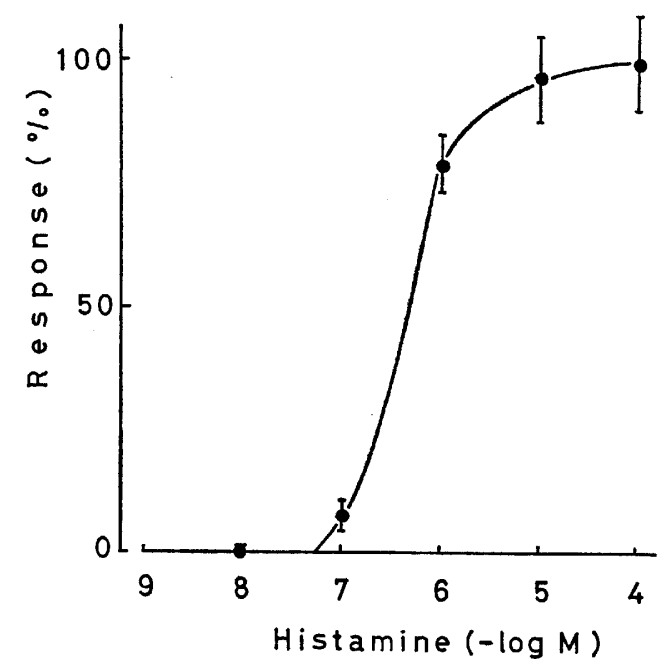

Fig. 7. Dose-response curve to histamine for several cell suspensions from guinea pig taenia caeci. Cell suspensions were exposed to various concentrations of histamine in modified Tyrode solution $\left(1.8 \mathrm{mM} \mathrm{Ca}^{2+}\right)$ for $20 \mathrm{sec}$. Each point is mean \pm S.E. $(n=$ 3-5). 


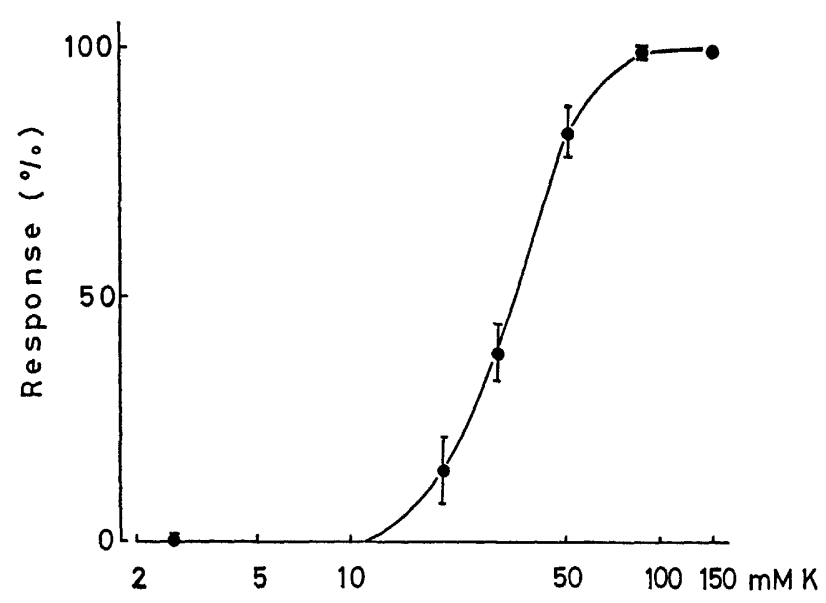

Fig. 8. Relationship between concentration of $\mathrm{K}^{+}$and degrees of contractile response in several cell suspensions from guinea pig taenia caeci. Cell suspensions were exposed to high $\mathrm{K}^{+}$solution $\left(1.8 \mathrm{mM} \mathrm{Ca}^{2+}\right)$ for $15 \mathrm{sec}$. Each point is mean \pm S.E. $(n=3-5)$.

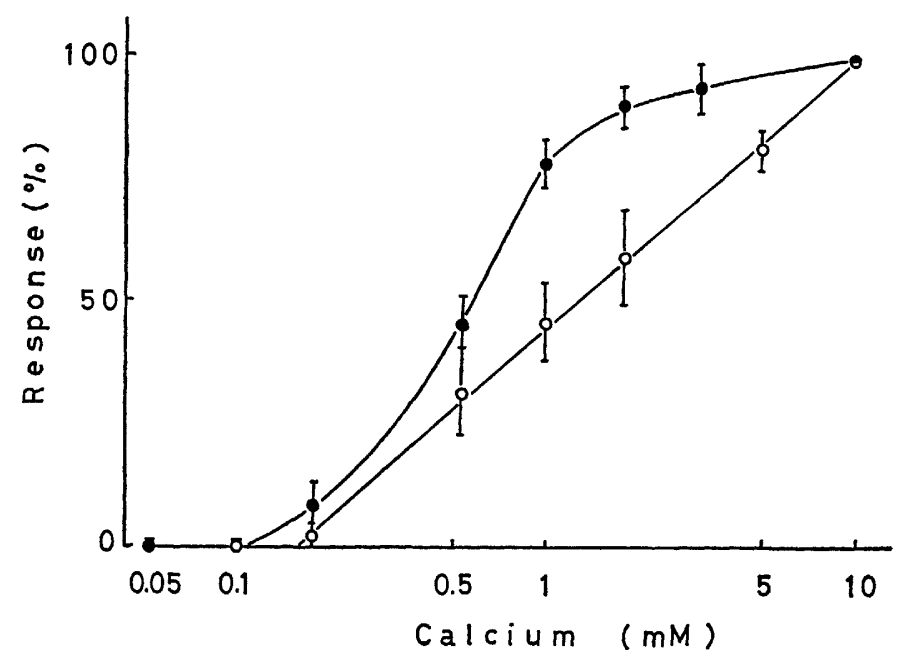

Fig. 9. Relationships between concentration of calcium and degrees of contractile response in several cell suspensions and several muscle strips from guinea pig taenia caeci. Calcium was applied under depolarized conditions $\left(140 \mathrm{mM} \mathrm{K} \mathrm{K}^{+}\right) . \quad$ e, single cells; $O$, muscle strips. Each point is mean \pm S.E. $(n=3-5)$.

\section{Effect of histamine}

As already shown in Fig. 3B, isolated single cells responded to histamine. The contractile responses were dose-dependent. The threshold concentration was approximately $6 \times 10^{-8} \mathrm{M}$. The maximal response was obtained at about $10^{-5} \mathrm{M}$ histamine. $\mathrm{ED}_{50}$ of histamine was about $5 \times 10^{-7} \mathrm{M}$ (Fig. 7). 

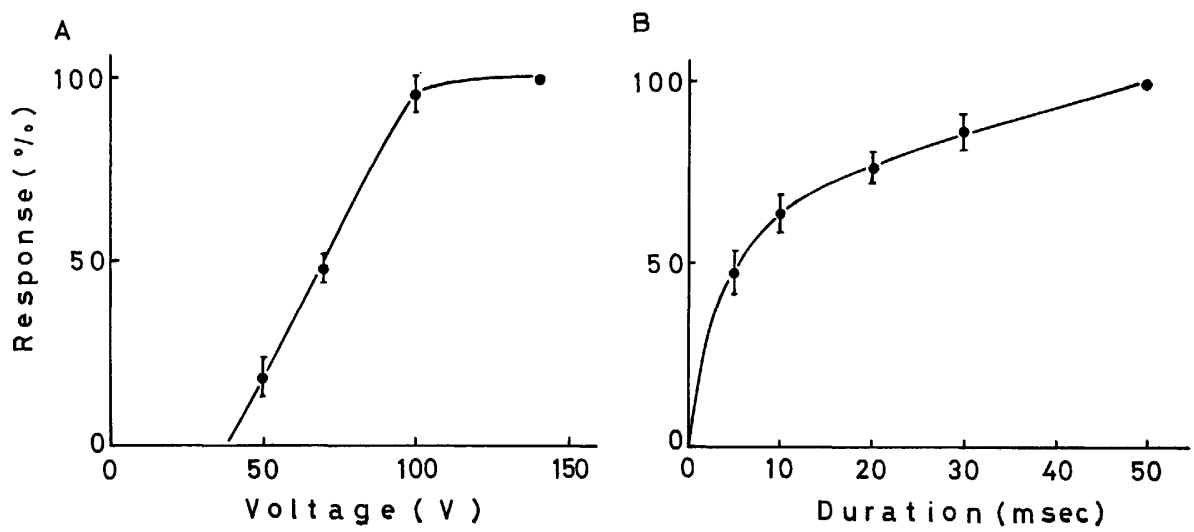

Fig. 10. Contractile responses of single cells from guinea pig taenia caeci to electrical stimulation. A, graded contraction of single cells elicited by single $20 \mathrm{msec}$ pulses of varying voltages in modified Tyrode solution $\left(1.8 \mathrm{mM} \mathrm{Ca}^{2+}\right)$; B, graded contraction of single cells elicited by single $140 \mathrm{~V}$ pulses of varying durations in modified Tyrode solution $\left(1.8 \mathrm{mM} \mathrm{Ca}^{2+}\right)$. Each point is mean \pm S.E. $(n=3)$.

\section{High $K^{+}$effect}

The kinetics of the contractile response to high $\mathrm{K}^{+}$is shown in Fig. 3C. The response to high $\mathrm{K}^{+}$was prompt, rising to a peak within $15 \mathrm{sec}$. After the peak, the contractile response declined to a plateau for the remainder of the period of observation $\left(2 \mathrm{~min}\right.$ ). Figure 8 shows that the contractile response to high $\mathrm{K}^{+}$ was concentration-related. The threshold concentration of $\mathrm{K}^{+}$required to induce response was less than $20 \mathrm{~mm}$. Maximal response was obtained with $85 \mathrm{~mm} \mathrm{~K}^{+}$.

\section{Ca contraction}

Single cells isolated from guinea pig taenia caeci were contracted using calcium under depolarized conditions $\left(140 \mathrm{mM} \mathrm{K}^{+}\right)$. This type of contraction was called "Ca contraction." Cells contracted as a result of a subsequent increase in the concentration of calcium chloride (Fig. 9). The threshold and maximal effective concentrations were about 0.1 and $4 \mathrm{~mm}$, respectively. Meanwhile, "Ca contraction" of muscle strips of guinea pig taenia caeci was also concentration-dependent. The threshold and maximal effective concentrations were about 0.17 and $10 \mathrm{~mm}$, respectively. The sensitivity of the single cells to calcium under depolarized conditions was higher than that of the muscle strips. The calcium concentrationresponse curve for the single cells was considerably steeper than that obtained for the muscle strips.

\section{Electrical stimulation}

When stimulus duration was constant $(20 \mathrm{msec})$ and voltage was varied, graded responses were obtained from the single cells. Responses were first obtained 
with about $50 \mathrm{~V}$, and successively higher voltages produced greater shortening (Fig. 10A). When stimulus voltage was constant $(140 \mathrm{~V})$ and stimulus duration varied, graded contractions resulted, with greater duration producing greater shortening (Fig. 10B).

\section{DISCUSSION}

A method is described for the isolation of single smooth muscle cells from guinea pig taenia caeci. This procedure is a modification of a technique originally described by Momose and Gomi (1980). Both the lowering of calcium from 0.18 to $0 \mathrm{~mm}$ and the increase of collagenase $(0.2$ to $0.3 \%)$ and trypsin inhibitor $(0.4$ to $0.6 \%$ ) caused a yield of single cells about 10 times higher than that in the procedure described by Momose and Gomi. About $80 \%$ of the control cells were more than $100 \mu \mathrm{m}$ in length and most of them were relaxed. The cell membrane appeared to be intact as judged by the ability of the cells to exclude trypan blue. The sensitivity of the single cells to $\mathrm{ACh}$ and calcium under depolarized conditions was higher than that shown by Momose and Gomi. Although the physiological concentration of $\mathrm{Ca}^{2+}, 1.8-2.2 \mathrm{~mm}$, was better in preserving the function of isolated cells, the incubation in $\mathrm{Ca}^{2+}$-free solution resulted in a high yield of the single cells accompanied by complete relaxation.

The shortening of isolated single cells induced by $\mathrm{ACh}$, histamine, high $\mathrm{K}^{+}$, and calcium under depolarized conditions was concentration-related (Figs. 7-9) and the shortening induced by electrical stimulation was voltage- and durationdependent (Fig. 10). Times determined for maximal response to $\mathrm{ACh}$, histamine and high $\mathrm{K}^{+}$in the single cells were shorter than those obtained for the muscle strips (IsHIYAma et al., 1975). This suggested that the mechanical responses of individual cells were not reflected in the contractile response of the muscle strip. In the present experiment, tension was not loaded on the single cells, whereas the muscle strip was loaded. This might be one of the reasons for the muscle strip requiring a longer period for maximal response. It was also assumed that cells in the strip could not contract synchronously, and some handicapped cells were still contracting in the final stage. It is also possible that elastic components such as collagen fibers might prolong the time course of contraction of the muscle strip.

The $\mathrm{ED}_{50} \mathrm{~S}$ of $\mathrm{ACh}$ in the single cells and in the muscle strips were about $2 \times$ $10^{-8}$ and $1.5 \times 10^{-7} \mathrm{M}$, respectively (Fig. 6). The sensitivity to ACh in the single cells was 10 times higher than that in the muscle strips. The higher sensitivity in the single cells is similar to that in the isolated single cells from the stomach of Bufo marinus reported by FAY and Singer (1977) and BitAR et al. (1979). This effect was possibly due to elimination or inactivation of cholinesterase during enzymatic digestion. Furthermore, the sensitivity of the single cells to calcium under depolarized conditions was higher than that of the muscle strips (Fig. 9). 
This suggested that the higher sensitivity of the single cells could be due to removal of diffusion barriers by the isolation of single cells.

On the other hand, Momose et al. (1981) reported that the sensitivity of the single cells to ACh was quite similar to that obtained with whole tissue. Significant differences exist between the results given in this paper and theirs in relation to the sensitivity of the single cells and whole tissue to ACh. It is possible that this difference is due to differences in the techniques used for dispersion of the single cells and measurement of contractile responses. The following differences are worthy of note. First, MOMOSE et al. (1981) used $0.2 \%$ collagenase and $0.4 \%$ trypsin inhibitor in a solution containing $0.18 \mathrm{mM} \mathrm{Ca}^{2+}$, whereas $0.3 \%$ collagenase and $0.6 \%$ trypsin inhibitor in $\mathrm{Ca}^{2+}$-free solution were used in this experiment. Secondly, Momose et al. determined the contractile responses in low calcium solution $(0.18 \mathrm{~mm})$, whereas they were determined in this experiment in a solution containing $1.8 \mathrm{mM} \mathrm{Ca}^{2+}$. Finally, it seems that the adherence of the cells on the glass slides caused the load of tension described in the method of measurement used by Momose et al.

Scanning electron-microscopic observations were undertaken in order to assess ultrastructural changes associated with contraction. The relaxed smooth muscle cell was very long and was characterized by a smooth surface (Fig. 5A). The generally smooth surface of the relaxed cell contrasts with the numerous evaginations present on the fully contracted cell (Fig. 5B). FAY and Delise (1973) observed similar structural changes associated with the contraction of isolated cells from the stomach of Bufo marinus. The formation of cellular evaginations may be understood as being due to the application of an inwardly directed force in plasma membrane-dense bodies, coupled with a general need to increase cellular diameter to accommodate the volume displaced by shortening of the cell. Thus those regions of the sarcolemma without dense bodies are forced outward to form blebs. During contraction, numerous blebs appear along the cell surface in observations made using a phase-contrast microscope (Fig. 4). It is considered that these surface irregularities correspond to those observed using a scanning electron microscope (Fig. 5B).

As mentioned above, a method is described for the isolation of single smooth muscle cells from taenia caeci of guinea pig. This method produced a high yield of cells. Most cells obtained by this procedure were relaxed and showed large contractile responses to a standard excitatory stimulus. I believe that single smooth muscle cells isolated from the guinea pig using my technique are, at present, better for many physiological and pharmacological studies than are cells isolated using other techniques.

I wish to express my thanks to Professor H. Yabu, Department of Physiology, Sapporo Medical College, for his valuable suggestions and discussion. I also wish to thank Dr. S. Muraoka, Department of Legal Medicine, and Mr. I. Kosaka, Department of Physiology, Sapporo Medical College, for technical assistance with the scanning electron microscope and for their helpful

Vol. 34, No. 1, 1984 
comments. This work was partially supported by a Grant-in-Aid for Scientific Research from the Ministry of Education, Science and Culture of Japan.

\section{REFERENCES}

BAGBY, R. M. and Fisher, B. A. (1973) Graded contractions in muscle strips and single cells from Bufo marinus stomach. Am. J. Physiol., 225: 105-109.

BitAR, K. N. and MAKHLOUr, G. M. (1982) Receptors on smooth muscle cells: Characterization by contraction and specific antagonists. Am. J. Physiol., 242: G400-G407.

BitAR, K. N., Zfass, A. M., and MaKhlouf, G. M. (1979) Interaction of acetylcholine and cholecystokinin with dispersed smooth muscle cells. Am. J. Physiol., 237: E172-E176.

FAY, F. S. and DeLISE, C. M. (1973) Contraction of isolated smooth muscle cells-structural changes. Proc. Natl. Acad. Sci. U.S.A., 70: 641-645.

FAY, F. S. and Singer, J. J. (1977) Characteristics of response of isolated smooth muscle cells to cholinergic drugs. Am. J. Physiol., 232: C144-C154.

IsHIYAMA, Y., YABU, H., and MIYAZAKI, E. (1975) Changes in contractility and calcium binding of guinea pig taenia coli by treatment with enzymes which hydrolyze sialic acid. Jpn. $J$. Physiol., 25: 719-732.

Momose, K. and GomI, Y. (1977) Studies on isolated smooth muscle cells. I. Continuous observation of contraction of single smooth muscle cells isolated from vas deferens of guinea pig. Chem. Pharm. Bull., 25: 2449-2451.

Momose, K. and Gom, Y. (1978) Studies on isolated smooth muscle cells. IV. Isolation and acetylcholine-contraction of single smooth muscle cells from taenia coli of guinea-pig. $J$. Pharm. Dyn., 1: 184-191.

Momose, K. and Gomi, Y. (1980) Studies on isolated smooth muscle cells. VI. Dispersion procedures for acetylcholine-sensitive smooth muscle cells of guinea pig. Jpn. J. Smooth Muscle Res., 16: 29-36 (in Japanese).

Momose, K., Otsuka, H., Higashikawa, S., and Gomi, Y. (1981) Studies on isolated smooth muscle cells. VII. Response to agonists and the contraction velocity of taenia coli of guinea pig and the single smooth muscle cells. J. Pharm. Dyn., 4: 670-676.

WALSH, J. V., Jr. and SiNGER, J. J. (1981) Voltage clamp of single freshly dissociated smooth muscle cells: Current-voltage relationships for three currents. Pfiügers Arch., 390: 207-210. 